Australian Journal of

Educational Technology

\title{
Strategies employed by users of a Japanese computer assisted language learning (CALL) program
}

\author{
Elizabeth Vincent and Maureen Hah \\ Monash University
}

\begin{abstract}
Significant use of Computer Assisted Language Learning CALL began in the 1960s. Since then development of CALL software has followed the changes in teaching methodologies. As teaching methods changed to audio-lingual and communicative approaches, CALL software included simulations and more interactive programs. Research has shown that learning strategies employed in $C A L L$ can affect the quality of learning in the language. A case study approach was used to investigate the language learning strategies employed by students using the NihingoWare I software for the learning of Japanese. The participants studied at Monash University in the Department of Japanese Studies. Investigation of the strategies used showed that there were special Program Use Strategies which have not previously been noted in language learning. In addition, language using strategies which are commonly used in non-computer learning situations were not employed by the participants. This suggests that computer software designers need to be aware of language learning strategies for effective design of CALL to enhance learning.
\end{abstract}

This paper examines strategies used in foreign language learning, and effects on these strategies resulting from use of computer assisted language learning (CALL) software. A recent study into (CALL) strategies using Japanese (Hah, 1994) has provided a basis for further research into the area of CALL strategies in foreign languages in general. The study of Japanese by Hah (1994) using NihingoWare 1, the most appropriate and complex software available at the time, utilised the language learning strategies described by Oxford (1990). The study aimed to establish the viability of using CALL in Japanese courses offered in Australia. 


\section{Foreign language learning strategies}

Much research has been done to find the best language teaching methods. What research has shown is that there is variety of effective approaches, and that clues could be gleaned from language learners themselves. Research began on learning styles used by language learners. Rubin and Thompson (1982) and Stevick (1989) were early pioneers to observe language learners and found specific learning methods which contributed to successful language learning. Students who are aware of their language learning strategies may be trained to apply and/or combine their strategies to be more effective learners. It was also found that less successful learners could be trained in effective language learning strategies (O'Malley, 1987; Wenden, 1987; O'Malley and Chamot, 1990; Oxford, 1990).

Although different researchers have proposed different schemes for the classification of learning strategies, Oxford (1990) added a robustness to the definition of learning strategies. Oxford viewed learning strategies as "specific actions taken by the learner to make leaning easier, faster, more enjoyable, more self directed, more effective, and more transferable to new situations" (p.8). The strategies were first divided into two main classes direct and indirect classes, each class comprising three strategy groups (cf. Figure 1).

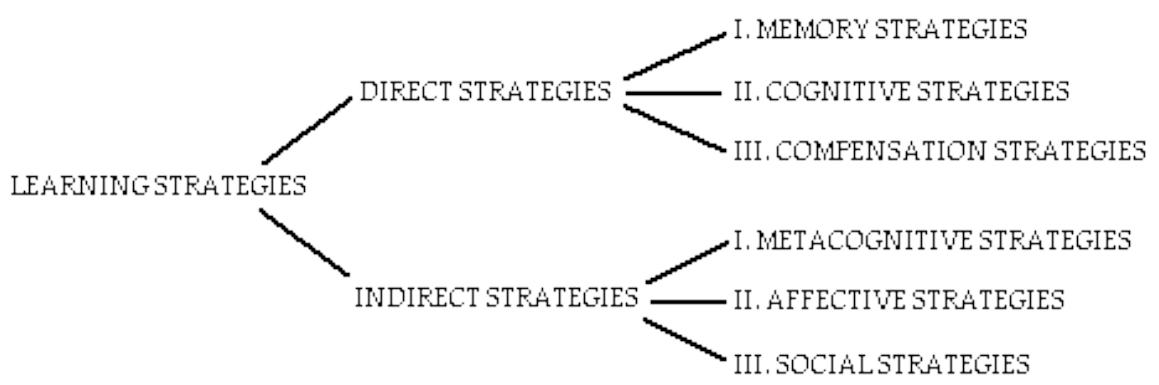

Figure 1: Direct and indirect strategies (Source: Oxford, 1990, p16)

The six strategy groups classified by Oxford (1990) interact and support each other. While the direct strategies worked with the language itself, indirect strategies coordinated the learning process. For example, memory (direct) strategies are used to create mental linkages between language items which are stored into structures for efficient retrieval. Metacognitive (indirect) strategies are employed to focus on that learning, keeping the learner's attention on the language items to be learnt. According to Oxford, 
it was natural for some of these strategies to overlap. When the learner is anxious and applies strategies to encourage him/herself, for example, the cognitive strategy of analysing and reasoning, the cause of the anxiety, is also applied. Oxford expands the six strategy groups into strategy sets, which are listed in Table 1.

Table 1: Strategy groups and strategy sets (Source: Oxford, 1990, p17)

\begin{tabular}{|c|c|c|c|}
\hline \multicolumn{2}{|c|}{ Direct Strategies } & \multicolumn{2}{|c|}{ Indirect Strategies } \\
\hline \multirow[t]{3}{*}{$\begin{array}{l}\text { I. Memory } \\
\text { strategies }\end{array}$} & $\begin{array}{l}\text { A. Creating mental } \\
\text { images }\end{array}$ & \multirow[t]{3}{*}{$\begin{array}{l}\text { I. Metacognitive } \\
\text { strategies }\end{array}$} & $\begin{array}{l}\text { A. Centering your } \\
\text { learning }\end{array}$ \\
\hline & $\begin{array}{l}\text { B. Applying images } \\
\text { and sounds }\end{array}$ & & $\begin{array}{l}\text { B. Arranging and } \\
\text { planning your } \\
\text { learning }\end{array}$ \\
\hline & C. Reviewing well & & $\begin{array}{l}\text { C. Evaluating your } \\
\text { learning }\end{array}$ \\
\hline \multirow[t]{4}{*}{$\begin{array}{l}\text { II. Cognitive } \\
\text { strategies }\end{array}$} & A. Practising & \multirow[t]{4}{*}{$\begin{array}{l}\text { II. Affective } \\
\text { strategies }\end{array}$} & $\begin{array}{l}\text { A. Lowering your } \\
\text { anxiety }\end{array}$ \\
\hline & $\begin{array}{l}\text { B. Receiving and } \\
\text { sending messages }\end{array}$ & & $\begin{array}{l}\text { B. Encouraging } \\
\text { yourself }\end{array}$ \\
\hline & $\begin{array}{l}\text { C. Analysing and } \\
\text { reasoning }\end{array}$ & & $\begin{array}{l}\text { C. Taking your } \\
\text { emotional }\end{array}$ \\
\hline & $\begin{array}{l}\text { D. Creating } \\
\text { structure for input } \\
\text { and output }\end{array}$ & & temperature \\
\hline \multirow{3}{*}{$\begin{array}{l}\text { III. } \\
\text { Compensation } \\
\text { strategies }\end{array}$} & $\begin{array}{l}\text { A. Guessing } \\
\text { intelligently }\end{array}$ & \multirow[t]{3}{*}{$\begin{array}{l}\text { III. Social } \\
\text { strategies }\end{array}$} & $\begin{array}{l}\text { A. Asking } \\
\text { questions }\end{array}$ \\
\hline & $\begin{array}{l}\text { B. Overcoming } \\
\text { limitations in }\end{array}$ & & $\begin{array}{l}\text { B. Cooperating } \\
\text { with others }\end{array}$ \\
\hline & $\begin{array}{l}\text { speaking and } \\
\text { writing }\end{array}$ & & $\begin{array}{l}\text { C. Empathising } \\
\text { with others }\end{array}$ \\
\hline
\end{tabular}

The terms 'learning style' and 'learning strategy' were once thought to be synonymous With research on learning strategies the terms were found to be distinct in their definitions and could not be applied interchangeably. Learning style covers a broad and generalised approach to learning, and 
influences the selection and application of learning strategies (Oxford, 1990). For the purpose of this study the definition of learning strategies and the detailed classification provided by Oxford will be adopted.

\section{Computers and language learning}

Significant use of CALL began in the early 1960s and its progress was greatly affected by the expanding capabilities of computer hardware. Development of CALL software followed changes in teaching methodologies. During the period when grammar translation approaches were adopted, drill and practice formats in CALL programs were commonly used. As teaching methods changed to audio-lingual and communicative approaches, CALL software included simulations and more interactive programs. Early research on CALL assessed software and methods of using it to measure its effectiveness on language learning. When learning strategies were found to be a significant factor in language learning, research on the relationship between CALL and learning strategies was carried out; the importance of research on characteristics and strategy use of successful CALL users and learners was reiterated by Dunkel (1991). Future research suggested by Chapelle and Jamieson (1991) includes the study of different types of language learners and CALL materials and tests to clarify whether students using CALL are more effective learners than those who did not use it.

There are advantages to introducing CALL to the learning of Japanese, despite the costs involved. Even if the critics argue that the sociocultural aspects of Japanese cannot be imparted by software, there are lower level skills which require development through repetitive practice. Most tertiary education institutions currently offering Japanese courses in Australia are limited by time constraints to providing an average of six hours per week of instruction and tutorials (Marriot et al., 1993). Language learning is the result of formal instruction but language development occurs beyond the classroom (Van Patten et al., 1987). Given that language learning should involve constant use of the target language in natural discourse (Ellis, 1992), learners require self-study and opportunities to practise the target language. Independent use and internalising of the language in a meaningful environment are necessary to supplement classroom learning. Moreover, some aspects of language acquisition require the development of lower-order skills. Independent self-study and self-pacing in natural discourse are some of the characteristics of CALL which provide these supplements.

\section{The study}

By early 1990 increasing student enrolments in Japanese language courses in Australian institutions indicated an upward trend in the study of Japanese in Australia. Research into the learning of Japanese is 
considerable, but research on the use of computers in the teaching or learning of Japanese is comparatively limited Moreover, there had not been evidence of research which combined the three aspects of learning strategies, CALL and Japanese. Given that each aspect continues to grow steadily in educational significance it seemed pertinent to investigate the following areas:

1. What language learning strategies listed by Oxford (1990) were exhibited by learners of Japanese while using CALL programs? Which strategies were more easily drawn upon through CALL?

2. Were there new language learning strategies not listed by Oxford (1990) which were used in a CALL environment?

3. Inversely were there language learning strategies listed by Oxford (1990) which were not applied when CALL was used?

Therefore this study (Hah, 1994) was based on the premise that firstly, the awareness and use of effective language learning strategies were the means to successful language learning; and secondly, that the strengths of CALL acted as catalysts to these learning strategies. There were limitations in the program, NihingoWare 1. It was not developed to teach Japanese scripts, the kanji or the kana, which explains the use of the alphabet or romanji in the program. This limitation invariably affected the results and set the parameters for the discussion.

The study probed and recorded evidence of language learning strategies by case study. Although case study methodology enhances a deeper understanding of the phenomena, it prohibits generalisation of the findings (Chapelle and Jamieson, 1991; Nunan, 1992). A pilot study was conducted to decide on a base level of proficiency in Japanese which learners would need. Two participants volunteered to be observed using the program. One did not have any experience with Japanese at all; the other had two semesters of Japanese at secondary level. Both volunteers were competent computer users and did not have any problems with the operations of the program. It was evident that the volunteer who did not have any experience with Japanese found significant difficulty learning the language within limited time. The volunteer who had learnt Japanese at school found the program more manageable and was able to understand basic Japanese in all the target expressions. It appeared that some foundation in Japanese was required to make reasonable progress with the program. It was therefore decided that Level A Japanese students in the Department of Japanese Studies at Monash University who had completed one level of Japanese would be suitable candidates as they had sufficient fundamental knowledge of the language to be able to understand the basic expressions in the program, and at the same time did not enough knowledge to find the program too easy. At a lecture, the eighty students were addressed as to the importance of the research and a survey form was also distributed. The survey was intended to gather student reactions 
to and opinions on the possible use of CALL programs in learning Japanese in the Department of Japanese Studies, and on the possibility of 'computer-phobia' among Japanese language students. Much literature is available to indicate that computers are widely used by and for students of mathematics and science but rarely used by nor for language and arts students. Some of the survey forms were returned giving a return rate of 44 percent. Volunteers for the actual study of the research then came forward.

Six participants were used in the research; Ari, Charly, Felicity, Jasmin, John, and Rose. From the research data form which the participants completed, a broad spectrum of variables were noted. First, there were differences in age and gender. Ari, Jasmin, John and Felicity were between the ages 17-20, Charly was 21-2:, and Rose was in the 45-50 and above age group. Next there were the computer background differences. Although the computer systems owned by the learners and the software they used were different, it did not appear to have much effect on their operational skills with the program. However, the accessibility and the frequency of the learner's use of the computer seemed to make a difference. There was a diversity of language backgrounds among the learners. Jasmin was familiar with another Asian language, Mandarin. For Charley and Rose, Japanese was the only foreign language they were learning. Felicity and John were first generation Australian born Italians and spoke Italian at home.

There was also variation in the courses which the learners were enrolled in and which provided motivational factors for their learning of Japanese. The topic selected from NihingoWare 1 in consultation with the Department of Japanese was Lesson 2, Eating out, as this situation had not been taught and would therefore be a new topic. At the same time, it had basic expressions which the learners were able to understand. Pre-tests and post-tests were conducted to assess the learners' levels of proficiency in Japanese. These tests encompassed writing, correctness of expression, comprehension and translation of Japanese. Two sessions were conducted with each participant and were videotaped. In the first session the students were given a free reign to explore the program. In the second session, the students adhered to the required task. The manual and a set of notes comprising an overview of the software were provided to the participants. Following the observations the participants were interviewed to clarify their attitudes to learner autonomy, learning strategies and their opinion of the software. The interviews were audio taped. The learners then completed a questionnaire for their opinion on CALL in general.

A substantial outline and analysis of the data can be found in Hah (1994). Most of the learning strategies outlined by Oxford (1990) were used. For 
example, all six participants demonstrated the use of the metacognitive strategy of "Identifying the purpose of the tasks" and another closely related metacognitive strategy, "Centring their Learning". It is worth noting that there were no indications of participants employing affective strategies like "Lower their anxiety", "Encourage themselves", or "Taking their emotional temperature". Naturally the social strategies were also not exhibited given that there was no one else to interact with besides the researcher. However from the post observational interviews some of the social strategies were evident, for example, "Developing a cultural understanding" and "Identifying with Japanese native speakers". Memory strategies such as "Semantic mapping", "Using keywords" and "Using a physical response or sensation" were not used by the participants. The program did not provoke the participants to employ action as a memory strategy. Two of the participants said that they liked to use memory cards but they did not write anything down on paper or card while they used the software because note-pads were not available during the session. They were not sufficiently induced to bring their own notepad for the second session. As a result the cognitive strategy of "Taking notes" was not displayed.

The case studies revealed that in the learning of Japanese a different collection of learning strategies - "Program Use Strategies" (Hah, 1994) were used; these strategies were found to be modifications or expansions of the learning strategies classified by Oxford (1990). These included "Using resources for learning", "Forming an overview and linking features already known material", "Use of the Hand-Cursor to trace words", "Practising" and rather than "Self-evaluation" as used by Oxford(1990), they showed they were "Aware of their own learning strategies" and used "Self-evaluation of the CALL program".

\section{Discussion}

Whether Program Use Strategies surfaced because of CALL or whether there were other causes is an area for further research. Of the learning strategies listed by Oxford (1990) which were not used by the participants in this study the reason may be attributed to the short duration given to the participants to work on the CALL program. The possibility of intervention to improve the quality of learning outcomes and processes (Ramsden, 1988) is aided by an awareness of the learning strategies employed by learners. Strategy training may be given to help students learn 'how to learn' thereby developing a conscious skill in self directed language learning. Research shows that learners who had received strategy training generally learnt better than those who did not (Oxford, 1990). The resulting learner autonomy would be particularly useful for distance education learners who do not have easy access to instructors. A study like those by Stevick (1989) and Dunkel (1991), of successful language learners using CALL programs, would reveal important 
strategies which may be used to increase the effectiveness of strategy training.

It is vital that the development of CALL materials match students' language learning strategies. Teachers are needed to diagnose learners' problems and manage learning experiences. This is important for the students' success. Ng and Oliver (1987) and Pusack (1988) were among those who advocated serious consideration for integration of CALL and language curriculum. However, Kemmis et al (1977) found that it was inevitable that the curriculum exerts a influence on CALL because it determines what is to be learnt and in turn, how it is to be learnt. This cyclic interaction between curriculum, pedagogy and resultant on-going changes make it difficult for the integration of CALL and the curriculum. CALL software is in reality often selected to suit existing hardware. The software developer also must take into account the language learning strategies of students both in conventional mediums as well as in CALL. For example, the absence of a note-pad within the NihingoWare 1 did not encourage the cognitive strategy of "Taking Notes".

CALL in Japanese language learning is viable provided the following conditions are appropriately sustained: adequate and appropriate teacher training in CALL, integration of CALL in the curriculum, and appropriate software development incorporating language learning strategies. In the 1960s the language laboratories failed because, among other factors, the potential of the language laboratories were not realised. The same concern should be given to CALL. Two important components are required for maximising the potential of CALL - teachers and curriculum integration. The role of teachers inevitably changes when learning strategies and CALL are emphasised in language learning. When the computer is utilised as a disseminator and source of information, teachers need to receive sufficient hands-on computer and CALL training to know and maximise the potential of CALL. Teacher training in CALL should be from the onset of training and involve the development of holistic understanding of computers in education (Lawson Jr., 1985). Research on hypermedia and multimedia technology may be carried out to examine whether course materials can be prepared without the prohibitive demand on teachers' time which was one of the major problems for the language learning laboratories.

\section{Conclusion and future directions}

With these initial findings about language learning strategies used in CALL environments, more questions have arisen:

- Social strategies were not evident in the participants because they worked alone in this study. Would language learning strategies of CALL users differ between individual users and those working in 
groups? Such findings would be important for the classroom situation when it is not likely for learners to have individual access to the computers. They would also be important for distance education users who would be expected to work individually without the presence of other learners.

- The use of the manual was minimal. After a glance at it in the initial use of the software it was put aside and not referred to except by one participant when they had a specific problem. What is the use of the manual? Should it be a requisite or an accessory? How comprehensive need it be?

- NihingoWare 1 used romanji instead of the Japanese script, kanji or the kana. Would this make a difference to the learning of communicative Japanese?

- How would factors like gender, age, and language background affect learning strategies and CALL?

Where there was no evidence of program use strategies by a learner, conventional mediums of learning may be more suitable. In the end it must be borne in mind that CALL must not be used just because computer technology is extensively applied in society. CALL may be a resource to be exploited or a teaching method to be used as long as it is designed to support learners' strategies.

\section{References}

Chapelle, C. and Jamieson, J. (1991). Internal and external validity issues in research on CALL effectiveness. In P. Dunkel (ed), Computer-Assisted Language Learning and Testing: Research Issues and Practice. New York: Newbury House.

Dunkel, P. (1991). Computer-Assisted Language Learning and Testing. Research Issues and Practices. New York: Newbury House.

Ellis, R. (1992). Second Language Acquisition and Language Pedagogy. Clevedon, UK: Multilingual Matters

Hah, M. L.(1994). Computer-Aided Language Learning (CALL) and Learning Strategies in the Learning of Japanese. M. Ed. Studies Dissertation, Monash University, Clayton.

Kemmis, S. Atkin, R. and Wright, E. (1977). How do students learn? Working papers on computer assisted leaning. Report by UNCAL (Understanding Computer Assisted Learning) Centre for Applied Research in Education, University of East Anglia, Norwich.

Lawson, H. W. Jr. (1987). Addressing fundamental problems in computer related education and training. In K. Duncan and D. Harris (eds), Computers in Education. BV (North Holland): Elsevier Science Publishers.

Marriot, H. E., Neustupny, J. V. and Spence-Brown, R. (1993). Unlocking Australia's Language Potential: Profiles of 9 Key Languages in Australia, Volume 7 Japanese. Canberra: National Languages and Literacy Institute of Australia (NLLIA).

Ng, E. K. L. and Oliver, W. P. (1987). Computer Assisted Language Learning: An investigation of some design and implementation Issues. System, 15(1), 1-17.

NihingoWare 1. An interactive Approach to Learning Business Japanese (1992). Ariadne Language Link Co Ltd: Webster, New York. 
Nunan, R. R. (1990). Research Methods in Language Learning. Cambridge: Cambridge University Press.

O'Malley, J. M. (1987). The effects of training in the use of learning strategies on acquiring English as a second language. In A. Weden and J. Rubin (eds), Learner Strategies for Language Learning. New York: Prentice-Hall.

O'Malley, J. M. and Chamot, A. U. (1990). Learning Strategies in Second Language Acquisition. Cambridge: Cambridge University Press.

Oxford, R. (1990). Language learning strategies: What every teacher should know. Boston: Heinle \& Heinle.

Pusack, J. P. (1988). Problems and prospects in foreign language computing. In W. F. Smith (ed), Modern Media in Foreign Language Education: Theory and Implementation. Chicago: National Textbook Co.

Ramsden, P. (1988). Context and Strategy: Situational Influences on Learning. In R. R. Schmeck (ed), Learning Strategies and Learning Styles. New York: Plenum Press.

Rubin, J. and Thompson, I. (1982). How to Be a More Successful Language Learner. Boston: Heinle \& Heinle.

Stevick, E. W. (1989). Success with Foreign Languages. Seven who achieved it and what worked for them. Hertfordshire: Prentice Hall International.

Van Patten, B., Dvorak, T. R. and Lee, J. F. (1987). Foreign Language Learning. A Research Perspective. New York: Newbury House.

Wenden, A. (1987). Incorporating learner training in the classroom. In A. Wenden and J. Rubin (eds), Learner Strategies for Language Learning. New York: Prentice Hall.

Elizabeth Vincent is involved in research and teaching at the Faculty of Education, Monash University (Clayton and Peninsula). Her background in teaching has extended the entire range of students from K-12 in private and government schools and also the tertiary sector. She has conducted research into the use of Music and Logo and is now extending this research interest into the Boxer environment and other platforms. Elizabeth's background in Mathematics, Computing and Music has provided her with a broad set of perspectives into learning in computer environments.

Maureen Hah's interest in language studies has emerged from the teaching of English language and literature as a foreign language at the MARA College of Science in Malaysia. She has researched in educational computing especially Computer Aided Language Learning at the Faculty of Eduction, Monash University.

Please cite as: Vincent, E. \& Hah, M. (1996). Strategies employed by users of a Japanese computer assisted language learning (CALL) program. Australian Journal of Educational Technology, 12(1), 25-34.

http: / / www.ascilite.org.au/ajet/ajet12/vincent.html 